7 - ORIGINAL ARTICLE WOUND HEALING

\title{
The acute effects of preoperative ozone theraphy on surgical wound healing ${ }^{1}$
}

\author{
Hasan Sahin', Tuncer Simsek', Hakan Turkon" ${ }^{\mathrm{II}}$, Yıldıray Kalkan ${ }^{\mathrm{III}}$, Faruk Ozkul ${ }^{\mathrm{IV}}$, M Turgut Alper Ozkan", Mesut Erbas ${ }^{\mathrm{VI}}$, \\ Ugur Altinisik', Yavuz Demiraran VII
}

DOI: http://dx.doi.org/10.1590/S0102-865020160070000007

\begin{abstract}
IAssistant Professor, Department of Anesthesiology and Reanimation, Faculty of Medicine, Canakkale Onsekiz Mart University, Canakkale, Turkey. Conception and design of the study; acquisition, analyzis and interpretation of data; manuscript writing; critical revision; final approved.

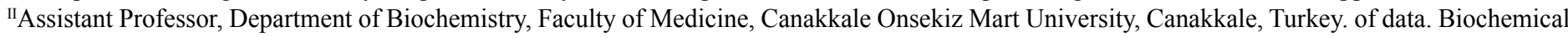
examinations, final approved.

IIIAssociate Professor, Department of Histology and Embryology, Faculty of Medicine, Recep Tayyip Erdoğan University, Rize, Turkey. Histopatological examinations, final approved.

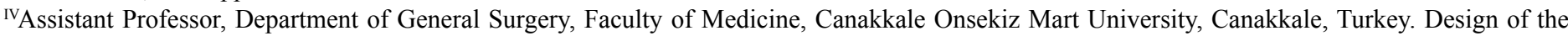
study, acquisition of data, final approved.

vAssistant Professor, Department of Cardiovascular Surgery, Faculty of Medicine, Canakkale Onsekiz Mart University, Canakkale, Turkey. Design of the study, acquisition and interpretation of data, final approved.

${ }^{\mathrm{V}}$ Associate Professor, Department of Anesthesiology and Reanimation, Faculty of Medicine, Canakkale Onsekiz Mart University, Canakkale, Turkey. Conception and design of the study, technical procedures, acquisition of data, final approved.

${ }^{\mathrm{VII}} \mathrm{MD}$, Department of Anesthesiology and Reanimation, Faculty of Medicine, Canakkale Onsekiz Mart University, Canakkale, Turkey. Critical revision, final approved.
\end{abstract}

\section{ABSTRACT}

PURPOSE: To investigate the effects of preoperative rectal ozone insufflation on surgical wound healing over the proinflammatory cytokines and histopathological changes.

METHODS: Twenty one rabbits were divided into 3 groups. Sham, surgical wound, and ozone applied (6 sessions, every other day 70 $\mu \mathrm{g} / \mathrm{mL}$ in $12 \mathrm{~mL} \mathrm{O}-\mathrm{O} 3$ mixture rectally) surgical wound groups were created. TNF-alpha and IL-6 levels from all rabbits were studied at the basal, 24th hour, and 72nd hour. The histopathological examination was done by removing the surgical scar tissue at the end of 72 nd hour.

RESULTS: TNF-alfa and IL-6 levels were significantly lower compared to the control group, in the rabbits treated with ozone. The increase in angiogenesis, the decrease in the number of inflammatory cells, epidermal and dermal regeneration, better collagen deposition, and increased keratinisation in stratum corneum were observed in the histopathological examination. It was determined that the wound healing noticeably accelerated in the ozone group.

CONCLUSION: Preoperative rectal ozone insufflation had a positive effect on surgical wound healing in acute period.

Key words: Ozone. Wound Healing. Rabbits. 


\section{Introduction}

Wound healing is clinically defined as the completion of the closure of the wounded skin area. This is a dynamic and interactive process which parenchymal cells, extracellular matrix, blood cells, and a variety of soluble mediators are involved in. Wound healing includes the phases of hemostasis, inflammation, cellular proliferation, matrix synthesis and remodeling, angiogenesis, and formation of granulation tissue ${ }^{1,2}$. Cytokines play an important role in the development and differentiation of T cells, B cells, and hematopoietic cells and stimulation or suppression of inflammation. The systemic effects of certain cytokines are more pronounced while some cytokines show regional impact ${ }^{3}$. IL-6 pulls marginal neutrophils in to circulation by increasing the life span and activation of neutrophils. It helps the migration of neutrophils from bone marrow to scar tissue. IL-6 causes the increase in the levels of vascular endothelial growth factor (VEGF) by showing synergistic effect with tumor necrosis factor $\alpha$ ( TNF $\alpha)$ and interleukin- 1 (IL-1). In this way, new vessel formation (angiogenesis) and endothelial cell proliferation are ensured ${ }^{4}$. Limiting the inflammation activated in the wound healing is important also for prognosis and healing process of the wound. It was shown the increase in expression of TNF- $\alpha$ inhibits collagen synthesis in the wound area ${ }^{1}$. Ozone is a gaseous molecule consisting three oxygen atoms. Ozone $\left(\mathrm{O}_{3}\right)$ is an unstable molecule in contrast to stable Oxygen molecule $\left(\mathrm{O}_{2}\right)$. Ozone therapy (OT) is sistematically effective when pathological and immunological processes are activated. There are ischemic and infectious conditions such as macular degeneration due to aging in these wound healing processes ${ }^{5}$.

Ozone causes a chain reaction when meet blood and activates antioxidant enzymes. These enzymes trigger many reactions, too and consequently better blood supply to the tissues is ensured by increasing the oxygen carrying capacity of blood. Cell alimentation, regeneration and the process of disposing toxins are accelerated by this effect. Therefore, there are cell metabolism activator and immunomodulator effects of ozone therapy, too besides its antioxidant effect ${ }^{6-7}$. Ozone has various therapeutic effects on wound healing due to the content of neutral oxygen which activates antioxidant enzymes and has bactericidal capacity $^{8-9}$.

In our study, we aimed to investigate the effects of preoperative rectal ozone insufflation on surgical wound healing, proinflammatory cytokines (IL-6 and TNF- $\alpha$ ) levels and histopathological changes.

\section{Methods}

The necessary permissions for the experiments were obtained from Çanakkale 18 Mart University Animal Experiments Ethics Committee and the study was conducted at the Experimental Research Center of Çanakkale 18 Mart University.

Twenty one adult New Zealand white rabbits at body weight $3.0-3.5 \mathrm{~kg}$ were used in this study. The rabbits were clinically examined in terms of behaviour, respiratory, cardiovascular system before starting the study and any negativeness was not determined in the animals included in the study.

During the experiment, the animals were fed with standard food, constantly they had opportunity to access to water. The temperature of the living environment was $21 \pm 2^{\circ} \mathrm{C}$ and the light was set to be as 12 hours dark 12 hours light. 21 rabbits were randomly divided into three groups;

Group $\mathrm{O}(\mathrm{n}=7)$ : Ozone group treated with $\mathrm{O}_{2}-\mathrm{O}_{3}$ mixture Group K ( $n=7)$ : Control group treated with air

Group S (n=7): Sham group

Six treatments every other day $70 \mu \mathrm{g} / \mathrm{mL}$ in $12 \mathrm{cc} \mathrm{O}_{2}-\mathrm{O}_{3}$ mixture was slowly insufflated rectally for 1 minute to Group $\mathrm{O}$. $10 \mathrm{Fr}$ nasogastric tube was cut to $5 \mathrm{~cm}$ for insufflation, the catheter tip was filed to avoid irritation of the rectal mucosa, and was placed $4 \mathrm{~cm}$ inside rectally by using lumric material. The same procedure was carried out by giving $12 \mathrm{cc}$ of air rectally to the Group K. Any treatment was not applied to Sham group.

The rabbits were fasted 12 hours before the operation. The blanket set to $39^{\circ} \mathrm{C}$ was laid to the ground to prevent heat loss during anesthesia. $5 \mathrm{mg} / \mathrm{kg}$ xylazine (Rompun ${ }^{\circledR}$, Bayer Healthcare LLC) and $30 \mathrm{mg} / \mathrm{kg}$ of ketamine $\mathrm{HCl}$ were injected into the quadriceps femoris muscles by planning the application of general anesthesia for approximately 20 minutes to the rabbits. 26 Gauge catheter was inserted into right marginal ear vein by checking the pedal and palpepral reflexes. Blood samples were taken into tubes for studying TNF- $\alpha$ and IL-6. $4 \mu \mathrm{g} / \mathrm{kg}$ fentail (FentanylJanssen, Janssen-Cilac, Beerse, Belgium) in intravenous $2 \mathrm{mg}$ / $\mathrm{kg}$ rocuronium bromure (Esmeron $50 \mathrm{mg} / 5 \mathrm{ml}$, Organon İlaç A.Ş. Istanbul, Turkey) to supress the respiration was given to all rabbits under sedation. It was supported with $100 \% \mathrm{O}_{2}$ by the appropriate face mask for the rabbit and Mapleson $\mathrm{C}$ pediatric ventilation circuit. V-gel Rabbit (R-3, Docsinnovent ${ }^{\circledR}$ Ltd. London, UK) airway device was placed by the same anesthesiologist when all rabbits were completely paralyzied ${ }^{10}$. Another anesthesiologist pulled the tongue to lateral by holding it for the easy insertion of airway device during this process. 


\section{Maintenance of anesthesia and laparotomy}

All experimental animals apart from the ones in Sham group were connected to the pediatric ventilator (MPV-10 Infant Transport Ventilatör, Bio-Med Devices, Connecticut, USA) combined with anesthesia device (Anesthesia Machine w/O2 Flush Model M3000PK Parkland Scientific Lab And Research Equipment. Florida, USA) by pediatric Jackson Rees circuit. Maintenance of anesthesia was provided using 1,5-2 MAC isofluran as to be the mixture of $50 \% \mathrm{O}_{2}$ and $50 \%$ air. Respiratory rate was ventilated as 40/min and pressure of $15 \mathrm{~cm} \mathrm{H} 2 \mathrm{O}$ (about tidal volume of $10 \mathrm{~mL} / \mathrm{kg}$ ) and 1:2 of inspiratory to expiratory ratio to comply with the rabbit physiology. Laparotomy was performed by $5 \mathrm{~cm}$ incision for the implementation of real anesthesia and surgical procedures to all rabbits from the fifth minute of anesthesia on and then the process of suturing was initiated, this process was continued until $15^{\text {th }}$ minute of maintenance of anesthesia. The inhilation agent was stopped at the $30^{\text {th }}$ minute and $4 \mathrm{mg} /$ $\mathrm{kg}$ intravenous dose of sugammadex was done to reverse muscle relaxation, the rabbits returning adequate spontaneous breathing back were extubated, the aspiration was supported with the mask for a while. The operated rabbits were monitored for 3 days. The bloods were drawn into suitable tubes at the $24^{\text {th }}$ and $72^{\text {nd }}$ hours of the experiment for studying TNF- $\alpha$ and IL-6. The rabbits were sacrifised under general anesthesia at the end of the $72^{\text {nd }}$ hour and samples taken from injured areas were placed in formalin for the histopathological examination of wound healing. Samples were taken from the appropriate places in accordance with the wounds of other rabbits and were placed in formalin in Sham group after sacrification.

\section{Analysis of inflammatory cytokines}

Rabbit serum IL-6, TNF-alpha levels were measured using an enzyme-linked immunosorbent assay (ELISA) kit (Rabbit TNF-Alpha Cat. No: CK-E91014, Rabbit IL-6 Cat.No: CK-E80171, Hangzhou Eastbiopharm Co. Ltd., Hangzhou, China) according to the manufacturer's instructions. The intra-assay and inter-assay coefficients of variations were $<10 \%$ and $<12 \%$ for rabbit IL-6 and TNF-alpha respectively.

\section{Histopathological examination}

Histopathological wound scores were examined by a pathologist and a histologist performing blind ratings. For this, 10 preparates from 1 animal in each group $(n=7)$ were obtained. Grading and statistics were made by categorizing the histopathological changes, such as granulation tissue thickening, epidermal regeneration, dermal regeneration, collagen distribution, angiogenesis, inflammatory cells as + (low $),++($ medium $),+++($ high $)$ and $++++($ very high $)$ on total of 200 areas by selecting 2 areas on each preparate. All groups were dyed with Hematoxylin Eosin and Masson's trichrome dyes.

\section{Statistical analysis}

The obtained data was compared using "IBM SPSS Statistics 19" statistical analysis software owned by Çanakkale Onsekiz Mart University. Wilcoxon test was used for the intragroup comparison of TNF- $\alpha$ and IL- 6 levels, Mann-Whitney $\mathrm{U}$ test was used for the intergoup comparison of TNF- $\alpha$ and IL-6 levels. Mann-Whitney $U$ test was used in the comparison of histopathological examination data. A p-value of less than 0.05 was considered to show a statistically significant result. Obtained results were tabulated and transferred to the graphs.

\section{Results}

\section{Inflammatory cytokines}

TNF- $\alpha$ : There was no statistically significant difference between the groups in comparison to basal values in all three groups ( $p>0.05)$. Any significant change was not observed in Group $\mathrm{S}$ in the intragroup assessments. A significant increase was observed at both $24^{\text {th }}$ hour $(p=0.018)$ and $72^{\text {nd }}$ hour $(p=0.018)$ compared with basal values in Group $\mathrm{K}$. The increase observed at the $24^{\text {th }}$ hour $(\mathrm{p}=0.306)$ and $72^{\text {nd }}$ hour $(\mathrm{p}=0.176)$ compared with basal values in Ozone treated group was not significant. There was not a significant difference between control and ozone groups $(p>0.05)$ while the significant increase $(p<0.05)$ was observed at the intergroup $24^{\text {th }}$ hour in both control group and ozone group compared to Sham group. The observed increase in control group and ozone group compared with Sham group at the intergroup $72^{\text {nd }}$ hour was statistically significant $(\mathrm{p}<0.05)$ (Table 1, Figure 1). 
TABLE 1 - TNF alpha and IL-6 levels and statistical intragoup comparison results.

\begin{tabular}{|c|c|c|c|c|c|c|}
\hline & \multicolumn{3}{|c|}{ TNF alfa levels } & \multicolumn{3}{|l|}{ IL-6 levels } \\
\hline & Basal & 24. hour & 72. hour & Basal & 24. hour & 72. hour \\
\hline Group S & $38.3 \pm 5.5$ & $33.1 \pm 1.1$ & $34.6 \pm 2.2$ & $23.1 \pm 4$ & $19.3 \pm 1.8$ & $20.2 \pm 3$ \\
\hline Group K & $36.1 \pm 5.4$ & $40.7 \pm 4.9^{\mathrm{a}}$ & $49 \pm 4.3^{b, c}$ & $24.6 \pm 4.6$ & $28.4 \pm 5.7$ & $51.5 \pm 13.2^{\mathrm{b}, \mathrm{c}}$ \\
\hline Group 0 & $36.7 \pm 5.6$ & $38.3 \pm 4.3$ & $40.4 \pm 2.7$ & $23.1 \pm 3.9$ & $26.2 \pm 5.1$ & $31 \pm 11$ \\
\hline
\end{tabular}

a:p $<0.05$ between basal to 24 . hour, b:p $<0.05$ between basal to 72 . hour, c:p $<0.05$ between 24 . to 72 . hour. Data are described as means \pm standard deviations.

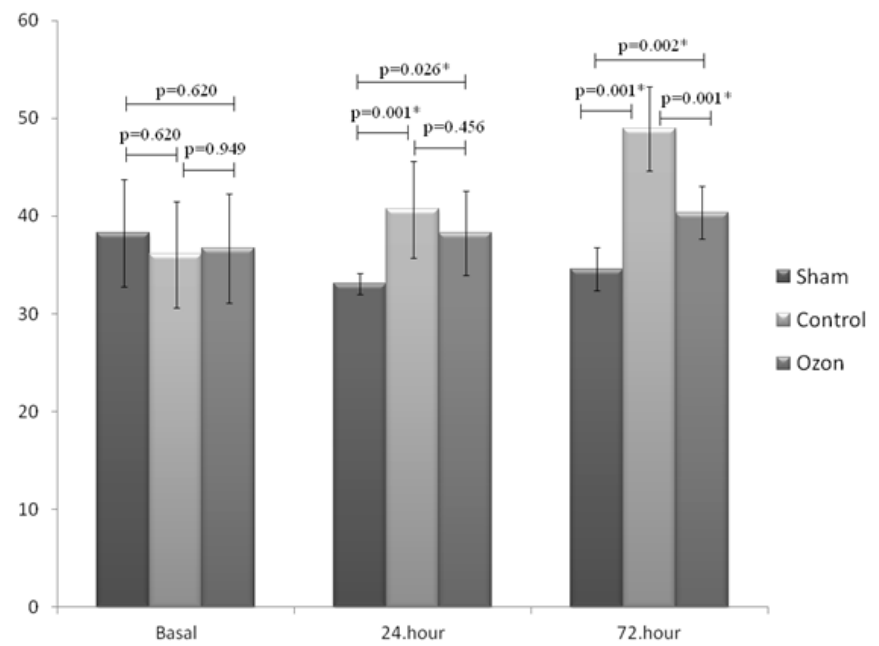

FIGURE 1 - Graphical representation of TNF alpha levels and statistical intergoup comparison results. Data are described as means \pm standard deviations.

IL-6: There was no statistically significant difference between the groups in comparison to basal values in all three groups ( $\mathrm{p}>0.05)$. Any significant change was not observed in Group $\mathrm{S}$ in the intragroup assessments. The increase at the $24^{\text {th }}$ hour was not significant compared with basal values in Group $\mathrm{K}$ $(p=0.176)$. When the values measured at basal- $72^{\text {nd }}$ hour $(p=0.043)$ and $24^{\text {th }}$ hour- $72^{\text {nd }}$ hour $(\mathrm{p}=0.033)$ were compared, asignificant increase was observed. There was not a significant increase at $24^{\text {th }}$ hour $(\mathrm{p}=0.499), 72^{\text {nd }}$ hour $(\mathrm{p}=0.310)$, and between $24^{\text {th }}-72^{\text {th }}$ hours $(\mathrm{p}=0.469)$ compared with basal values in Group O. There was no significant difference between control and ozone groups ( $p>0.05)$ while a significant increase at the intergroup $24^{\text {th }}$ hour in both control and ozone groups compared with Sham group. At the intergroup $72^{\text {nd }}$ hour, there was not a significant difference between Sham-ozone and control-ozone groups $(\mathrm{p}>0.05)$ while there was a significant difference between Sham and control groups $(p<0.05)$ (Table 1, Figure 2).

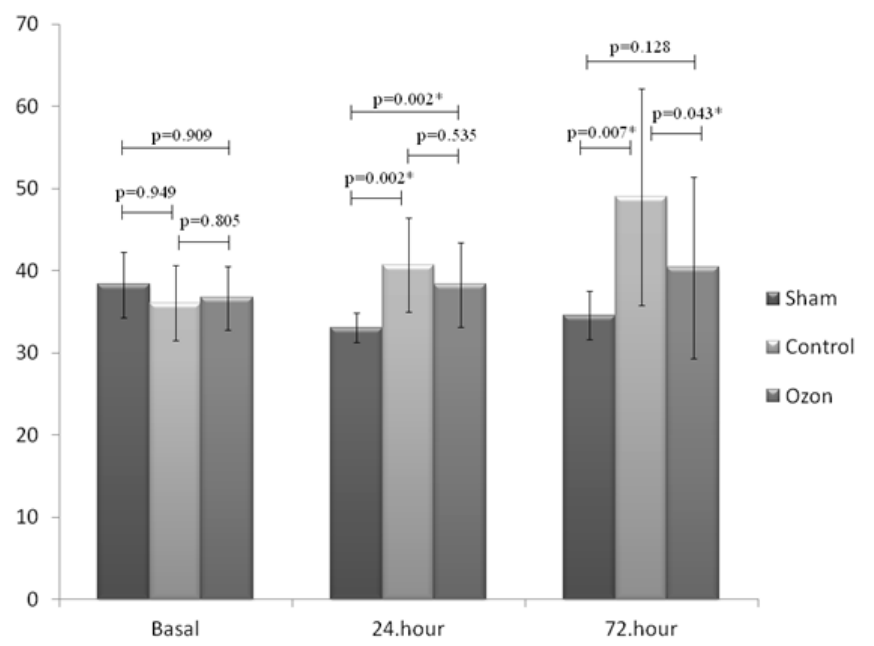

FIGURE 2 - Graphical representation of IL-6 levels and statistical intergoup comparison results. Data are described as means \pm standard deviations.

\section{Histopathological examination}

Tissue samples had the normal histological appearance and the cells on layers were easily distinguished by morphological features in Group S (Figure 3, Table 2). Increased angiogenesis and vasculogenesis, along with the regeneration of the epidermal and dermal, prominently increasing wound thickness due to the formation of granulation tissue, the indistinct cells located in the upper epidermal layer were observed in Group K. Though the limits of Squamous epithelial layers are not certain, it was determined that re-epithelialization increased due to this the edema areas were taken shape between the connective tissue in the dermal layer. It was seen that inflammatory cell infiltrations increased in areas close to the veins, the cells formed groups in such a way that forming clusters from place to place (Figure 4, Table 2). 


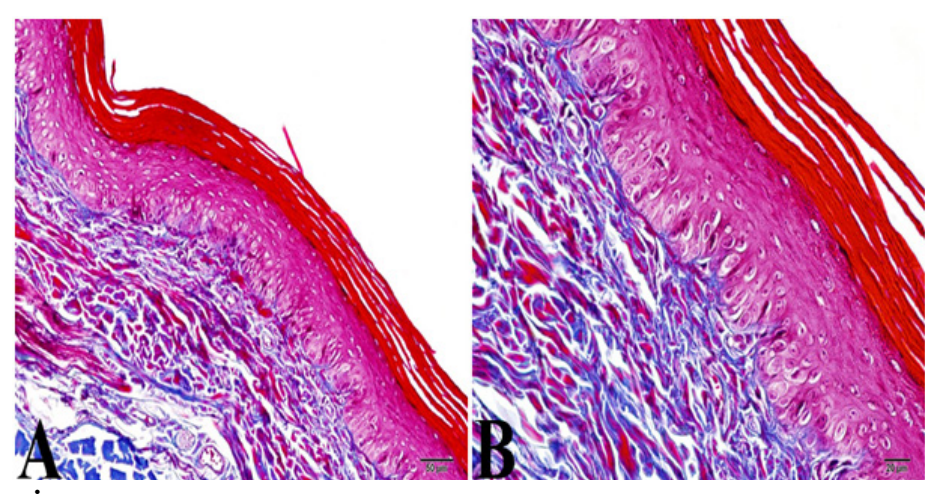

FIGURE 3 - Sham group. Masson Trichrome staining. Normal tissue appearance.

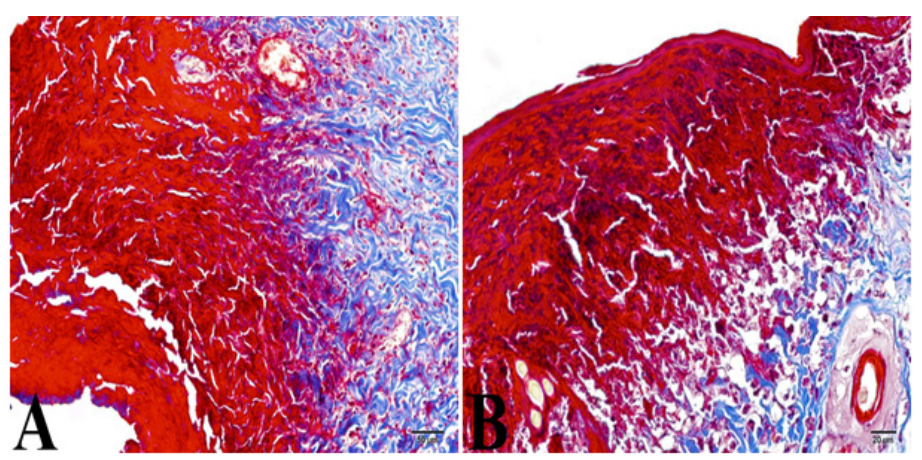

FIGURE 4 - Control group. Masson Trichrome staining. Histopathological appearance consistent with significant tissue injury.

TABLE 2 - Histopathological grading of all groups.

\begin{tabular}{|c|c|c|c|c|c|c|}
\hline Group & $\begin{array}{c}\text { Granülasyon doku } \\
\text { kalınlaşması }\end{array}$ & $\begin{array}{l}\text { Epidermal reje- } \\
\text { nerasyon }\end{array}$ & $\begin{array}{c}\text { Dermal } \\
\text { rejenerasyon }\end{array}$ & $\begin{array}{l}\text { Kollajen } \\
\text { dağ } 11 \text { lım } 1\end{array}$ & Angiogenesis & $\begin{array}{l}\text { İnflamatuar } \\
\text { hücreler }\end{array}$ \\
\hline Grup S & $0.00 \pm 0.42$ & $1.00 \pm 0.48$ & $1.00 \pm 0.52$ & $1.00 \pm 0.00$ & $0.00 \pm 0.97$ & $0.00 \pm 0.42$ \\
\hline Grup K & $2.00 \pm 0.52^{\mathrm{a}}$ & $2.00 \pm 0.00^{\mathrm{a}}$ & $2.00 \pm 0.42^{\mathrm{a}}$ & $2.00 \pm 0.70^{\mathrm{a}}$ & $2.00 \pm 0.67^{\mathrm{a}}$ & $3.50 \pm 0.69^{\mathrm{a}}$ \\
\hline Grup O & $3.00 \pm 0.32^{\mathrm{a}, \mathrm{b}}$ & $3.00 \pm 0.00^{\mathrm{a}, \mathrm{b}}$ & $3.00 \pm 0.32^{\mathrm{a}, \mathrm{b}}$ & $4.00 \pm 0.48^{\mathrm{a}, \mathrm{b}}$ & $3.00 \pm 0.57^{\mathrm{a}, \mathrm{b}}$ & $2.00 \pm 0.00^{\mathrm{a}, \mathrm{b}}$ \\
\hline
\end{tabular}

a:A significant difference was found in the statistics done in terms of histopathological changes such as granulation tissue thickness, epidermal regeneration, dermal regeneration, collagen distribution, angiogenesis, inflammatory cells according to Mann-Whitney U test done between Group $\mathrm{S}$, Group K, and Group O ( $<<0.05$ ).

${ }^{\mathrm{b}}$ :A significant difference was found in the statistics done in terms of histopathological changes such as granulation tissue thickness, epidermal regeneration, dermal regeneration, collagen distribution, angiogenesis, inflammatory cells according to Mann-Whitney U test done between Group $\mathrm{K}$ and Group O ( $<<0.05$ ).

It was seen that in Group $\mathrm{O}$, angiogenesis and vasculogenesis increased more, these areas were found to be better identified with especially Mason staining. It was observed that granulation tissue was prominently formed together with epidermal and dermal regeneration, the thickness of the wound was less than Group K. It was determined that especially the cells located in the upper part of the epidermal layer became distinct and keratinisation on stratum korneum emerged. Though the limits of Squamous epithelial layers are not certain, it was seen that the borders of the cell could be identified and angiogenesis, vasculogenesis, and re-epithelialization markedly increased compared to Group K.

Despite the edema areas between the connective tissue in the dermal layer are similar to Group K, it was observed that the thickness of collagen threads increased and collagen deposition was higher in this group. It was seen that inflammatory cell infiltrations were in areas close to the veins, but the cells were in a single view in a manner that not to form groups (Figure 5, Table 2). It was observed that the wound healing process proceeded more slowly in the control group. It was determined that the wound healing was prominently accelarated in Ozone group.

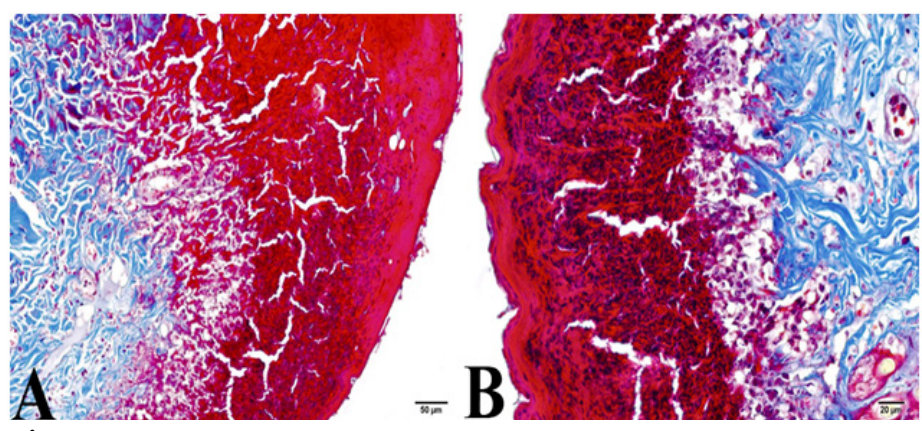

FÍGURE 5 - Ozone group. Masson Trichrome staining. Histopathological appearance consistent with better wound healing process.

\section{Discussion}

The decrease was observed in the proinflammatory cytokines; TNF alpha and IL-6 in the ozone treated group in our study. It was seen that the prominent formation of granulation tissue along with the regeneration of the epidermal and dermal, the wound thickness was less, angiogenesis, vasculogenesis, and re-epithelialization intensely increased in the histopathological examination. It was observed that the thickness of collagen tissue 
increased and collagen deposition was higher in this group and wound healing was prominently faster.

Ozone is a molecule which affects systemically ${ }^{5}$. It triggers reactions that affecting each other, when it is taken into the body. The increase in antioxidant level and the reduction in lipid peroxidation occur at the end of these reactions. This effect reverts in a short time. Ozone also activates "heme oxygenase 1" enzyme, too. This enzyme has antioxidant, antiapoptotic, and antiinflammatory effects ${ }^{11}$.

It is reported that many factors have effects on wound healing ${ }^{12,13}$. There are studies investigating the effects of ozone treatment on infected wound healing. Lelyanov et al. for the first time, investigated the effects of ozone on wound healing ${ }^{14}$. In that study, it was reported that ozone made a positive contribution to the healing of colonic anastomosis wound. Again, Erginel et al. looked for the effect of ozone on colonic anastomosis wound healing in a rat model of peritonitis and stated that wound healing was better in the ozone treated groups, in their study ${ }^{15}$. It was determined that topical application of ozone had healing effects on acute skin wounds ${ }^{16}$. We observed that ozone had healing effects on surgical wounds of rabbits that we applied prophylactic ozone postoperatively in our study. Wound healing was found to be prominently accelerated in the rabbits treated with ozone. When we looked through in terms of histopathological changes such as granulation tissue thickening, epidermal regeneration, dermal regeneration and collagen distribution, angiogenesis, inflammatory cells, we observed that ozone had positive effects on wound healing at the same time.

Many studies have reported that various cell sources contribute to the production of cytokines in wound $1^{7,18}$. Proinflammatory cytokins; TNF alpha and IL-6 have negative effects on wound healing ${ }^{19}$. The decrease on levels of these cytokins will create positive impact on wound healing. We evaluated the antiinflammatory effects through these mediators in our study. Though there was not statistically significant decrease in IL-6 and TNF alpha overall values, it was found to be lower in ozone treated group compared with control group.

In the histopathological examination in our study, the decrease in the number of anti-inflammatory cells and also reduction of proinflammatory cytokine levels suggested that antiinflammatory activity of ozone had a positive effect on wound healing. Especially the increment of the cells located in the upper part of the epidermal layer in ozone treated group compared to control group was consistent with the reduction of cell apoptosis. Though the edema areas between connective tissue in the dermal layer was similar to control group, collagen deposition was higher in the ones treated with ozone made us think that ozone made a positive contribution to wound healing with its antioxidant property.

Kim et $a l .{ }^{16}$ reported that the sizes of wound were small, collagen fibers and fibroblasts prominently increased in the ozone treated group in their study of local application of ozone on acute cutaneus wound healing. It was shown that reduction of wound size and the significant increase in collagen fibers after ozone treatment on diabetic wound ${ }^{20}$. These results suggest us the positive effect on wound healing of the ozone might be associated with its antiinflammatory, antiapoptotic, and antioxidant properties.

\section{Conclusion}

Preoperative rectal application of ozone had positive effects on wound healing in acute period.

\section{References}

1. Delavary BM, van der Veer WM, van Egmond M, Niessen FB, Beelen RH. Macrophages in skin injury and repair. Immunobiology. 2011 Jul;216(7):753-62. doi: 10.1016/j.imbio.2011.01.001.

2. Çevikbaş U. Basic pathology. İstanbul: Nobel Tıp Kitabevi;1995.

3. Dalkılıç E, Gül CB, Alkış N. Interleukin-6: one of the leading actors on inflammation. Uludağ Üniversitesi Tıp Fakültesi Dergisi. 2012;38(2):157-160.

4. Dayer JM, Choy E.Therapeutic targets in rheumatoid arthritis: the interleukin-6 receptor. Rheumatology (Oxford). 2010 Jan;49(1):1524. doi: 10.1093/rheumatology/kep329.

5. Erginel B, Erginel T, Aksoy B, Dokucu Aİ. Effect of ozone therapy (OT) on healing of colonic anastomosis in a rat model of peritonitis. Balkan Med J. 2014 Sep;31(3):249-53. doi: 10.5152/ balkanmedj.2014.13215.

6. Bocci V. Ozone as Janus: this controversial gas can be either toxic or medically useful. Mediators Inflamm. 2004 Feb;13(1):3-11. doi: 10.1080/0962935062000197083.

7. Calunga JL, Zamora ZB, Borrego A, Río Sd, Barber E, Menéndez $\mathrm{S}$, Hernández F, Montero T, Taboada D. Ozone therapy on rats submitted to subtotal nephrectomy: role of antioxidant system. Mediators Inflamm. 2005 Aug 31;2005(4):221-7. doi: 10.1155/ MI.2005.221.

8. Bocci V, Borrelli E, Travagli V, Zanardi I. The ozone paradox: ozone is a strong oxidant as well as a medical drug. Med Res Rev. 2009 Jul;29(4):646-82. doi: 10.1002/med.20150.

9. Agrillo A, Filiaci F, Ramieri V, Riccardi E, Quarato D, Rinna C, Gennaro P, Cascino F, Mitro V, Ungari C. Bisphosphonate-related osteonecrosis of the jaw (BRONJ): 5 year experience in the treatment of 131 cases with ozone therapy. Eur Rev Med Pharmacol Sci. 2012 Nov;16(12):1741-7. doi: 10.2147/cia.s67726.

10. Toman H, Erbas M, Kiraz HA, Sahin H, Ovali MA, Uzun M. Comparison of effects of classic LMA, cobraPLA and V-gel rabbit on QTc interval. Bratisl Lek Listy. 2015;116(10):632-6. doi: 10.4149/bll_2015_122.

11. Özler M, Öter Ş, Korkmaz A. The use of ozone gas for medical purposes. TAF Preventive Med Bull. 2009;8:59-64.

12. Naves CC. The diabetic foot: a historical overview and gaps in current treatment. Adv Wound Care (New Rochelle). 2016 May 1;5(5):191-7. doi: 10.1089/wound.2013.0518 
Sahin $\mathrm{H}$ et al.

13. Norman G, Dumville JC, Mohapatra DP, Owens GL, Crosbie EJ. Antibiotics and antiseptics for surgical wounds healing by secondary intention. Cochrane Database Syst Rev. 2016;3:CD011712. doi: 10.1002/14651858.CD011712.pub2.

14. Lelyanov AD, Sergienko VI, Ivliev NV, Emelyanov VV, Guseva ED. Effects of sodium hypochlorite and ozone on healing of intestinal anastomosis in simulated strangulation colorectal obstruction. Bull Exp Biol Med. 2004;137:103-5. doi: 10.1023/b:bebm.0000024399.34545.cd.

15. Erginel B, Erginel T, Aksoy B, Dokucu Aİ. Effect of ozone therapy (OT) on healing of colonic anastomosis in a rat model of peritonitis. Balkan Med J. 2014 Sep;31(3):249-53. doi: 10.5152/ balkanmedj.2014.13215.

16. Kim HS, Noh SU, Han YW, Kim KM, Kang H, Kim HO, Park YM.Therapeutic effects of topical application of ozone on acute cutaneous wound healing. J Korean Med Sci. 2009 Jun;24(3):36874. doi: 10.3346/jkms.2009.24.3.368.

17. Eming SA, Krieg T, Davidson JM. Inflammation in wound repair: molecular and cellular mechanisms. J Invest Dermatol. 2007 Mar;127(3):514-25. doi: 10.1038/sj.jid.5700701.

18. Kiwanuka E, Junker J, Eriksson E. Harnessing growth factors to influence wound healing. Clin Plast Surg. 2012 Jul;39(3):239-48. doi: 10.1016/j.cps.2012.04.003.

19. Anderson JM, McNally AK. Biocompatibility of implants:lymphocyte/macrophage interactions. Semin Immunopathol. 2011 May;33(3):221-33. doi: 10.1007/s00281-0110244-1.

20. Zhang J, Guan M, Xie C, Luo X, Zhang Q, Xue Y. Increased growth factors play a role in wound healing promoted by noninvasive oxygen-ozone therapy in diabetic patients with foot ulcers. Oxid Med Cell Longev. 2014;2014:273475. doi: 10.1155/2014/273475.

\section{Correspondence:}

Hasan Sahin

Department of Anesthesiology and Reanimation, Faculty of Medicine Canakkale Onsekiz Mart University

Canakkale Turkey

Phone: +902862635950

Fax: +902862635956

drhasan@comu.edu.tr

Received: Mar 20, 2016

Review: May 25, 2016

Accepted: Jun 19, 2016

Conflict of interest: none

Financial source: none

${ }^{1}$ Research performed at Departments of Anesthesiology and Biochemistry, School of Medicine, Canakkale Onsekiz Mart University, Canakkale, Turkey. 


\section{Erratum}

Manuscript: The acute effects of preoperative ozone theraphy on surgical wound healing

Publication: Acta Cir Bras. 2016;31(7):472-8.

DOI: http://dx.doi.org/10.1590/S0102-865020160070000007

On page of the original publication, instead of this Table 2:

TABLE 2 - Histopathological grading of all groups.

\begin{tabular}{ccccccc}
\hline Group & $\begin{array}{c}\text { Granülasyon doku } \\
\text { kalınlaşması }\end{array}$ & $\begin{array}{c}\text { Epidermal } \\
\text { rejenerasyon }\end{array}$ & $\begin{array}{c}\text { Dermal } \\
\text { rejenerasyon }\end{array}$ & $\begin{array}{c}\text { Kollajen } \\
\text { dağ } 1 \text { limı }\end{array}$ & $\begin{array}{c}\text { Angiogenesis } \\
\text { İnflamatuar } \\
\text { hücreler }\end{array}$ \\
\hline Grup S & $0.00 \pm 0.42$ & $1.00 \pm 0.48$ & $1.00 \pm 0.52$ & $1.00 \pm 0.00$ & $0.00 \pm 0.97$ & $0.00 \pm 0.42$ \\
Grup K & $2.00 \pm 0.52^{\mathrm{a}}$ & $2.00 \pm 0.00^{\mathrm{a}}$ & $2.00 \pm 0.42^{\mathrm{a}}$ & $2.00 \pm 0.70^{\mathrm{a}}$ & $2.00 \pm 0.67^{\mathrm{a}}$ & $3.50 \pm 0.69^{\mathrm{a}}$ \\
Grup O & $3.00 \pm 0.32^{\mathrm{a}, \mathrm{b}}$ & $3.00 \pm 0.00^{\mathrm{a}, \mathrm{b}}$ & $3.00 \pm 0.32^{\mathrm{a}, \mathrm{b}}$ & $4.00 \pm 0.48^{\mathrm{a}, \mathrm{b}}$ & $3.00 \pm 0.57^{\mathrm{a}, \mathrm{b}}$ & $2.00 \pm 0.00^{\mathrm{a}, \mathrm{b}}$ \\
\hline
\end{tabular}

${ }^{\mathrm{a}}$ :A significant difference was found in the statistics done in terms of histopathological changes such as granulation tissue thickness, epidermal regeneration, dermal regeneration, collagen distribution, angiogenesis, inflammatory cells according to Mann-Whitney U test done between Group S, Group K, and Group O (p<0.05).

b:A significant difference was found in the statistics done in terms of histopathological changes such as granulation tissue thickness, epidermal regeneration, dermal regeneration, collagen distribution, angiogenesis, inflammatory cells according to Mann-Whitney $\mathrm{U}$ test done between Group $\mathrm{K}$ and $\mathrm{Group} \mathrm{O}$ ( $\mathrm{p}<0.05$ ).

Consider this Table 2:

TABLE 2 - Histopathological grading of all groups.

\begin{tabular}{|c|c|c|c|c|c|c|}
\hline Group & $\begin{array}{c}\text { Granulation Tissue } \\
\text { Thickening }\end{array}$ & $\begin{array}{c}\text { Epidermal } \\
\text { Regeneration }\end{array}$ & $\begin{array}{c}\text { Dermal } \\
\text { Regeneration }\end{array}$ & $\begin{array}{c}\text { Collagen } \\
\text { Distribution }\end{array}$ & Angiogenesis & $\begin{array}{c}\text { Inflammatory } \\
\text { Cells }\end{array}$ \\
\hline Grup S & $0.00 \pm 0.42$ & $1.00 \pm 0.48$ & $1.00 \pm 0.52$ & $1.00 \pm 0.00$ & $0.00 \pm 0.97$ & $0.00 \pm 0.42$ \\
\hline Grup K & $2.00 \pm 0.52^{\mathrm{a}}$ & $2.00 \pm 0.00^{\mathrm{a}}$ & $2.00 \pm 0.42^{\mathrm{a}}$ & $2.00 \pm 0.70^{\mathrm{a}}$ & $2.00 \pm 0.67^{\mathrm{a}}$ & $3.50 \pm 0.69^{a}$ \\
\hline Grup O & $3.00 \pm 0.32^{\mathrm{a}, \mathrm{b}}$ & $3.00 \pm 0.00$ a,b & $3.00 \pm 0.32^{\mathrm{a}, \mathrm{b}}$ & $4.00 \pm 0.48^{\mathrm{a}, \mathrm{b}}$ & $3.00 \pm 0.57^{\mathrm{a}, \mathrm{b}}$ & $2.00 \pm 0.00^{\mathrm{a}, \mathrm{b}}$ \\
\hline
\end{tabular}

a:A significant difference was found in the statistics done in terms of histopathological changes such as granulation tissue thickness, epidermal regeneration, dermal regeneration, collagen distribution, angiogenesis, inflammatory cells according to Mann-Whitney U test done between Group $\mathrm{S}$, Group K, and Group O ( $\mathrm{p}<0.05$ ).

${ }^{\mathrm{b}}$ :A significant difference was found in the statistics done in terms of histopathological changes such as granulation tissue thickness, epidermal regeneration, dermal regeneration, collagen distribution, angiogenesis, inflammatory cells according to Mann-Whitney U test done between Group K and Group O ( $<<0.05$ ). 